\title{
CTLA-4 (+49A/G) Polymorphism in Type 1 Diabetes Children of Sudanese Population
}

\author{
Khalid E. Khalid Kheiralla1,20 \\ 1 Department of Basic Medical Sciences, Faculty of Applied Medical \\ Sciences, Albaha University, Al Bahah, Saudi Arabia \\ 2 Department of Biochemistry and Nutrition, Faculty of Medicine, \\ University of Gezira, Wad Madani, Sudan \\ Global Med Genet 2021;8:11-18.
}

\begin{abstract}
Address for correspondence Khalid E. Khalid Kheiralla, PhD, Department of Basic Medical Sciences, Faculty of Applied Medical Sciences, Albaha University, Saudi Arabia; Department of Biochemistry and Nutrition, Faculty of Medicine, University of Gezira, Sudan (e-mail: khatahir12@gmail.com).
\end{abstract}

\begin{abstract}
Keywords

- CTLA-4

- polymorphism

- type 1 diabetes Mellitus

- Sudanese

Background Type 1 diabetes mellitus (T1DM) is an organ-specific T cell-mediated autoimmune disease, characterized by destruction of pancreatic islets. Cytotoxic lymphocyte antigen-4 (CTLA-4) is a negative regulator of $\mathrm{T}$ cell proliferation, thus conferring susceptibility to autoimmunity.

Aims This study aimed to investigate the association of CTLA-4 +49A/G (rs231775) polymorphism with a risk of T1DM in Sudanese children.

Methods This a case-control study included 100 children with T1DM, referred to the pediatric clinic at referral pediatric teaching hospital in Gezira State-Sudan. Hundred unrelated healthy controls were recruited from departments in the same hospital. Genomic deoxyribonucleic acid (DNA) was extracted from Ethylenediaminetetraacetic Acid (EDTA)-preserved blood using QIAamp DNA Blood Mini Kit (QIAamp Blood) (QIAGEN; Valencia, CA). The polymerase chain reaction PCR restriction fragment length polymorphism (PCR-RFLP) and sequencing were applied for the CTLA-4 (+49A/G) genotyping. The changes accompanied the polymorphism were evaluated using relevant bioinformatics tools.

Results The genotype and allele frequencies of the CTLA-4 (+49A/G) polymorphism were significantly different between the patients and controls $(p=0.00013$ and 0.0002 , respectively). In particular, the frequency of the $G$ allele, GG homozygous genotype, and AG heterozygous genotype were significantly increased in patients than in controls ( $[28 \%$ versus $7 \%$, odds ratio $(O R)=5.16,95 \%$ confidence interval $[\mathrm{Cl}]=2.77-9.65, p=0.00][12 \%$ versus $2 \%, \mathrm{OR}=6.68, \mathrm{Cl}=1.46-30.69, p=0.01]$ [ $32 \%$ versus $10 \%, \mathrm{OR}=4.24, \mathrm{Cl}=1.95-9.21, p=0.00$ ], respectively). The presence of the $G$ allele (homozygous) showed an influence on the signal peptide polarity, hydrophobicity, and $\alpha$-helix propensity of the CTLA-protein.

Conclusion The results further support the association of CTLA-4 $(+49 \mathrm{~A} / \mathrm{G})$ polymorphism and the risk of T1DM in our study population.
\end{abstract}

\section{Introduction}

Type 1 diabetes mellitus (T1DM) is an organ-specific and T cell-mediated autoimmune disease primarily affects children and adolescents. Cytotoxic lymphocyte antigen-4 (CTLA-4) is a member of the immunoglobulin superfamily

published online

February 15, 2021
DOI https://doi.org/

$10.1055 / \mathrm{s}-0041-1723008$.

ISSN 2699-9404. that is expressed on the surface of activated $\mathrm{T}$ cells and downregulates $\mathrm{T}$ cell function. ${ }^{1}$ In the mid-nineties, the CTLA-4 gene was reported as one of the important susceptibility genes in $\mathrm{T} 1 \mathrm{DM},{ }^{2}$ since that time, attentions have been made toward the exact role of this gene. Polymorphisms in the CTLA-4 gene have been identified and were found to be

(C) 2021. The Author(s).

This is an open access article published by Thieme under the terms of the Creative Commons Attribution License, permitting unrestricted use, distribution, and reproduction so long as the original work is properly cited. (https://creativecommons.org/licenses/by/4.0/)

Georg Thieme Verlag KG, Rüdigerstraße 14, 70469 Stuttgart, Germany 
associated with susceptibilities to a wide range of $\mathrm{T}$ cellmediated autoimmune diseases. ${ }^{3}$

One of these polymorphisms was the CTLA-4 $+49 \mathrm{~A} / \mathrm{G}$ single nucleotide polymorphism (SNP) that causes a threonine-to-alanine substitution in codon 17 , which altered protein expression ${ }^{4}$ and $\mathrm{T}$ cell activation. ${ }^{5}$ Since the $+49 \mathrm{~A} / \mathrm{G}$ SNP is located in the N-terminal of the signal peptide sequence of the CTLA-4, which is not a part of the mature protein, the substitution of threonine to alanine may affect the proper translocation of the growing CTLA-4 peptide from ribosome to endoplasmic reticulum (ER) lumen, as a result of alteration in signal peptide hydrophobicity and helix propensity, ${ }^{6}$ rendered possible evidence of defective CTLA- 4 targeting to the cell surface. ${ }^{7}$

The association of CTLA-4 polymorphisms with the risk to develop T1DM has been investigated in different populations with conflicting data. ${ }^{8}$ Recent study has shown no association between the aforementioned SNPs and susceptibility toT1DM among Sudanese adults. ${ }^{9}$ Since Sudanese population is characterized by multiethnic groups, the search for further association between groups of different age and ethnicity could likely help pursuing conclusive remarks about this association. In the present study, we investigated the association of the CTLA-4 +49A/G SNP with the risk of T1DM among Sudanese children and the proposed effect of this polymorphism on the CTLA-4 signal peptide instability.

\section{Subjects and Methods}

\section{Patients and Sampling}

This is a case-control study that encompasses 100 Sudanese children with T1DM (48 males and 52 females; mean age, $11.49 \pm 3.38$ ), referred to the diabetic clinic at Wad Medani Pediatric Hospital in Gezira state, Sudan. The selected patients were clinically diagnosed with T1DM, their disease duration was more than 1 year, and they are dependent on insulin therapy. The patients were classified based on the hemoglobin A1c $\left(\mathrm{HbA}_{1 \mathrm{c}}\right.$ ) levels into poor glycemic control $>8 \%$ and well glycemic control $\leq 8 \%$, as stated on the American Diabetes Association (ADA) and Japan Diabetes Society (JDS) guidelines. ${ }^{10,11}$ The demographic characteristics, clinical presentations, $\mathrm{Hb}_{\mathrm{A} 1 \mathrm{c}}$ levels, concomitant complications, and the presence of other autoimmune diseases were all reported in well-structured questionnaire. The control group includes 100 unrelated healthy children ( 44 males and 56 females; mean age, $11.49 \pm 3.38$ ) without or family history of T1DM or any other autoimmune diseases. The controls were recruited from departments in the same hospital, they lived in the same state, and they have ethnic background similar to the patients.

The study met the University of Gezira ethical committee review board requirements, and granted the permission to be performed from the hospital clinical directorate and the diabetic clinical staff as well. Signed written informed consent was obtained from the parents or guardians of all study subjects, after they informed about the study objectives and procedures.

Five-milliliter $(5 \mathrm{~mL})$ blood sample was taken in the morning (before breakfast) in EDTA container. Serum was separated to measure the $\mathrm{HbA}_{1 \mathrm{c}}$ by chromatographic-spectrophotometer ion exchange (BioSystems, United States), and the pellet used for the deoxyribonucleic acid (DNA) analysis of CTLA-4 $+49 \mathrm{~A} / \mathrm{G}$ genotypes.

\section{DNA Extraction and CTLA-4 Amplification}

Genomic DNA was extracted using QIAamp DNA Blood Mini Kit (QIAamp Blood) (QIAGEN, Valencia, CA). The desired fragment of the CTLA-4 gene was amplified by polymerase chain reaction (PCR) using CTLA-4 gene-specific forward

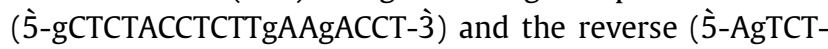
CACTCACCTTTgCAg-3) primers, which amplified 207 fragments of CTLA-4 gene.

Approximately, $0.2 \mathrm{mg}$ genomic DNA was amplified in $25 \mathrm{~mL}$ PCR reaction containing $10 \mathrm{mM}$ of each dNTPs (iStarTaq, iNtRon Biotech, Korea), $5 \mathrm{U}$ of Taq DNA polymerase (i-StarTaq, Korea), $2.5 \mathrm{~mL}$ of 10X PCR buffer, and $100 \mathrm{pmol} /$ $\mathrm{mL}$ of each primer (Sinagen, Iran). Reaction conditions were performed in PCR thermocycler (Eppendorf, Germany), starting with initial denaturation at $94^{\circ} \mathrm{C}$ for 4 minutes followed by 34 cycles of denaturation at $94^{\circ} \mathrm{C}$ for 30 second annealing at $60^{\circ} \mathrm{C}$ for 30 seconds elongation at $72^{\circ} \mathrm{C}$ for 2 minutes, and final extension at $72^{\circ} \mathrm{C}$ for 5 minutes. Then $5 \mu \mathrm{L}$ of the PCR product was run in $2 \%$ agarose gel electrophoresis to check the target PCR product at 207 bp length $(\boldsymbol{- F i g . ~ 1 A )}$.

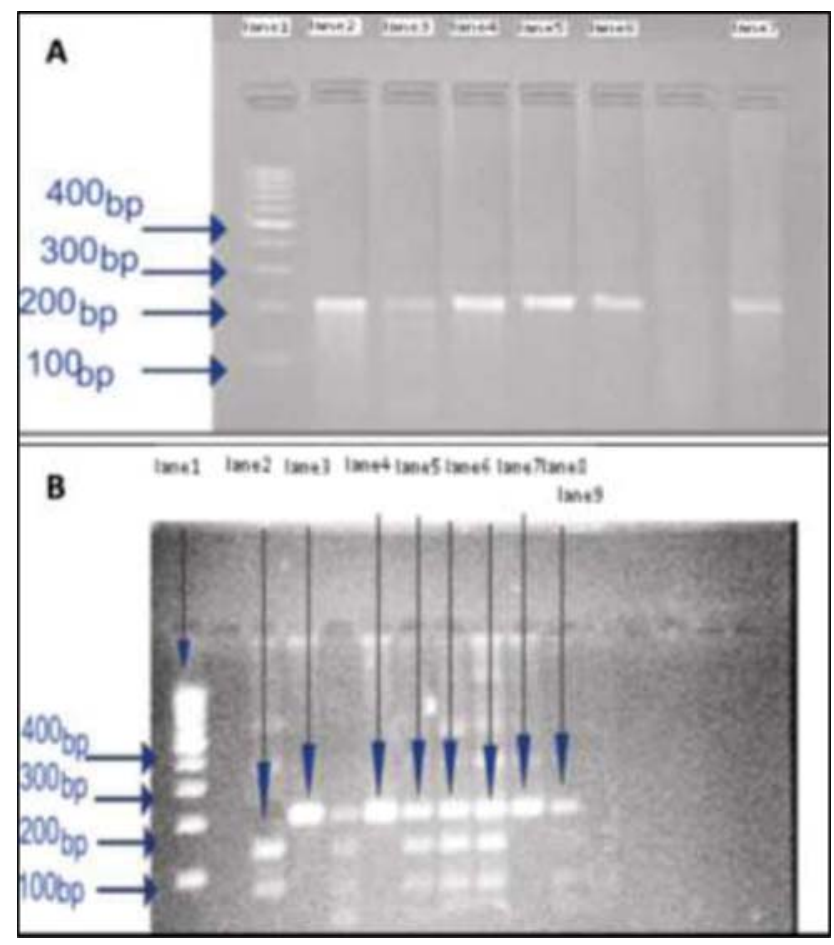

Fig. 1 (A) Confirmation of the genomic deoxyribonucleic acid (DNA) in patients and controls. Lane 1: DNA ladder $100 \mathrm{bp}$. The band appeared in lane 2 to 7 showed the polymerase chain reaction (PCR) product length of 207 bp for the CTLA-4 target gene in exon 1. (B) Fragment size for CTLA-4 $(+49 \mathrm{~A} / \mathrm{G})$ polymorphism in diabetic patients and controls by FastDigest Bbvl (LSP1109I, Germany). Lane 1: DNA ladder 100 bp; the bands in lane 3, 4,7 , and 8 represent allele $A$ at $207 \mathrm{bp}$, whereas fragments of band $G$ at 168 and 49 bp appear in lane 2, 5, and 6. Lanes 5, 6, 7: heterozygous (AG) genotype. Lanes 3, 4, 7, 8: homozygous (AA) genotype. Lane 2 homozygous (GG). CTLA-4, cytotoxic T-lymphocyte antigen-4. 
Restriction Fragment Length Polymorphism Analysis Restriction fragment length polymorphism (RFLP) analysis was conducted using FastDigest BbvI (Fermentas, Germany) in $30 \mu \mathrm{L}$ total volume that includes $10 \mu \mathrm{L}$ amplification product, $1.0 \mu \mathrm{L}$ $(10 \mathrm{U} / \mathrm{mL})$ of the restriction enzyme, $2.0 \mu \mathrm{L} 10 \mathrm{X}$ fast digest green buffer, and $17 \mu \mathrm{L}$ nuclease-free water. All components were mixed gently, spinned down, and incubated for 10 minutes at $37^{\circ} \mathrm{C}$ followed by heating at $65^{\circ} \mathrm{C}$ for 10 minutes. DNA fragments were visualized in $2.0 \%$ agarose gels exposed to UV light in a gel documentation system (Ingenus, United States). The restriction cut showed two fragments (49/168 bp) for the G allele and one fragment (207bp) for A allele ( - Fig. 1B). Direct DNA sequencing by Sanger method on an ABI 3730 sequencer (Macrogen, South Korea) was performed for 20 patients and 20 control by using $25 \mu \mathrm{L}$ of each PCR result independently, to validate the RFLP results. The sequencing results were analyzed using BLAST and Clustal X at the NCBI webpage.

\section{Bioinformatics Analysis Tools}

I-mutant version 3 (http://gpcr2.biocomp.unibo.it/cgi/predictors/1-Mutant3.0/) was used to predict the effect of the CTLA-4 +49 A/G SNP in proteins stability. ${ }^{12}$

Table 1 Demographic characteristics of the patients and the controls

\begin{tabular}{|c|c|c|c|}
\hline \multicolumn{2}{|l|}{ Characteristics } & \multirow{2}{*}{$\begin{array}{l}\begin{array}{l}\text { T1DM } \\
(n=100)\end{array} \\
48\end{array}$} & \multirow{2}{*}{$\begin{array}{l}\begin{array}{l}\text { Controls } \\
(n=100)\end{array} \\
56\end{array}$} \\
\hline Gender & Male & & \\
\hline & Female & 52 & 44 \\
\hline \multirow[t]{5}{*}{ Age group/yrs. } & Mean \pm SD & $11.49 \pm 3.38$ & $10.24 \pm 4.31$ \\
\hline & $<5$ & 2 & 24 \\
\hline & $5-9.9$ & 26 & 38 \\
\hline & $10-14.9$ & 50 & 30 \\
\hline & $\geq 15$ & 22 & 8 \\
\hline \multirow[t]{2}{*}{ Residence } & Rural & 80 & 54 \\
\hline & Urban & $2(2.0)$ & 46 \\
\hline \multicolumn{2}{|l|}{ Insulin dependent } & All & None \\
\hline \multicolumn{2}{|l|}{ Age at disease onset (years) } & $3-16$ & NA \\
\hline \multicolumn{2}{|l|}{ T1DM duration } & $4.35 \pm 3.02$ & NA \\
\hline \multirow[t]{2}{*}{ Family history of diabetes } & Negative & 64 & $\mathrm{NA}$ \\
\hline & Positive & 36 & NA \\
\hline \multirow[t]{3}{*}{ Glycemic control } & $\mathrm{HbA}_{1 \mathrm{c}}$ mean level & $10.68 \pm 2.17$ & $6.05 \pm 1.40^{\mathrm{a}}$ \\
\hline & $\mathrm{HbA}_{1 \mathrm{c}}<8 \%$ & 12 & 94 \\
\hline & $\mathrm{HbA}_{1 \mathrm{c}}>8 \%$ & 88 & 6 \\
\hline \multirow[t]{2}{*}{ Breast feeding } & Yes & 45 & NA \\
\hline & No & 55 & NA \\
\hline \multirow[t]{5}{*}{ BMI $\left(\mathrm{kg} / \mathrm{m}^{2}\right)$} & Range & $16.74 \pm 2.90$ & $19.4 \pm 4.74^{\mathrm{a}}$ \\
\hline & Underweight $\left(<18.5 \mathrm{~kg} / \mathrm{m}^{2}\right)$ & 80 & 52 \\
\hline & Normal $\left(18.5-24.9 \mathrm{~kg} / \mathrm{m}^{2}\right)$ & 18 & 28 \\
\hline & Overweight $\left(25-29.9 \mathrm{~kg} / \mathrm{m}^{2}\right)$ & 1 & 16 \\
\hline & Obese $\left(\geq 30 \mathrm{~kg} / \mathrm{m}^{2}\right)$ & 1 & 4 \\
\hline \multirow[t]{2}{*}{ On treatment } & Regular & All & NA \\
\hline & Not regular & - & $\mathrm{NA}$ \\
\hline \multirow[t]{4}{*}{ Disease complications } & Eye complication & 9 & $\mathrm{NA}$ \\
\hline & Renal complication & 1 & NA \\
\hline & Hypoglycemia & 45 & $\mathrm{NA}$ \\
\hline & Ketoacidosis & 63 & NA \\
\hline \multirow[t]{2}{*}{ Autoimmune diseases } & No & 92 & NA \\
\hline & Celiac disease & 8 & NA \\
\hline
\end{tabular}

Abbreviations: BMI, body mass index; HbA1c, hemoglobin A1c; NA, not applicable; SD, standard deviation; T1DM, type 1 diabetes mellitus. ${ }^{a} p<0.05$. 
Sorting Intolerant from Tolerant (SIFT) was used to predict whether an amino acid substitution affects protein function or not, based on the degree of amino acids conservation residues in sequence alignments derived from closely related sequences. The main underlying principle of this program is that it generates alignments with large number of homologous sequences, and assigns scores to each residue ranging from zero to one. Score close to zero indicates evolutionary conservation of the gene and intolerance to substitution, while score close to one indicates only

Table 2 Genotypes and alleles frequencies of CTLA-4 +49A/G polymorphism in T1DM patients and controls

\begin{tabular}{|c|c|c|c|c|c|}
\hline CTLA-4 variants & $\begin{array}{l}\text { T1DM } \\
(n=100)\end{array}$ & $\begin{array}{l}\text { Controls } \\
(n=100)\end{array}$ & OR & $95 \% \mathrm{Cl}$ & $p$-Value \\
\hline \multicolumn{6}{|c|}{ Genotype frequencies $^{a}$} \\
\hline $\begin{array}{l}\text { AA } \\
\text { (normal) }\end{array}$ & $56(56)$ & $88(88)$ & 0.17 & $0.08-0.36$ & 0.00 \\
\hline $\begin{array}{l}\text { AG } \\
\text { (heterozygous) }\end{array}$ & $32(32)$ & $10(10)$ & 4.24 & $1.95-9.21$ & 0.00 \\
\hline GG (homozygous) & $12(12)$ & $2(2)$ & 6.68 & $1.46-30.69$ & 0.01 \\
\hline \multicolumn{6}{|l|}{ Allele frequencies ${ }^{\mathrm{b}}$} \\
\hline${ }^{*} \mathrm{~A}$ allele & $144(72)$ & $186(93)$ & 1.94 & $0.10-0.36$ & 0.00 \\
\hline${ }^{* *} \mathrm{G}$ allele & $56(28)$ & $14(7)$ & 5.16 & $2.77-9.65$ & 0.00 \\
\hline
\end{tabular}

Abbreviations: $\mathrm{Cl}$, confidence interval; CTLA-4, cytotoxic T-lymphocyte antigen-4; OR, odds ratio; T1DM, type 1 diabetes mellitus. ${ }^{\mathrm{a}} \mathrm{p}=0.00013$.

${ }^{\mathrm{b}} p=0.0002$

*Adenine.

${ }^{*}$ Guanine.

Table 3 The SIFT score for the CTLA-4 SNP (rs231775)

\begin{tabular}{|l|l|l|l|l|l|l|l|}
\hline SNP ID & Organism/Build & Ref allele & Alt allele & $\begin{array}{l}\text { Amino acid } \\
\text { change }\end{array}$ & Gene name & $\begin{array}{l}\text { SIFT } \\
\text { score }\end{array}$ & SIFT prediction \\
\hline rs231775 & Homo_sapiens/GRCh37.74 & A & G & T17A & CTLA-4 & 0.06 & Tolerated \\
\hline
\end{tabular}

Abbreviations: CTLA-4, cytotoxic T-lymphocyte antigen-4; SIFT, Sorting Intolerant from Tolerant; SNP, single nucleotide polymorphism.

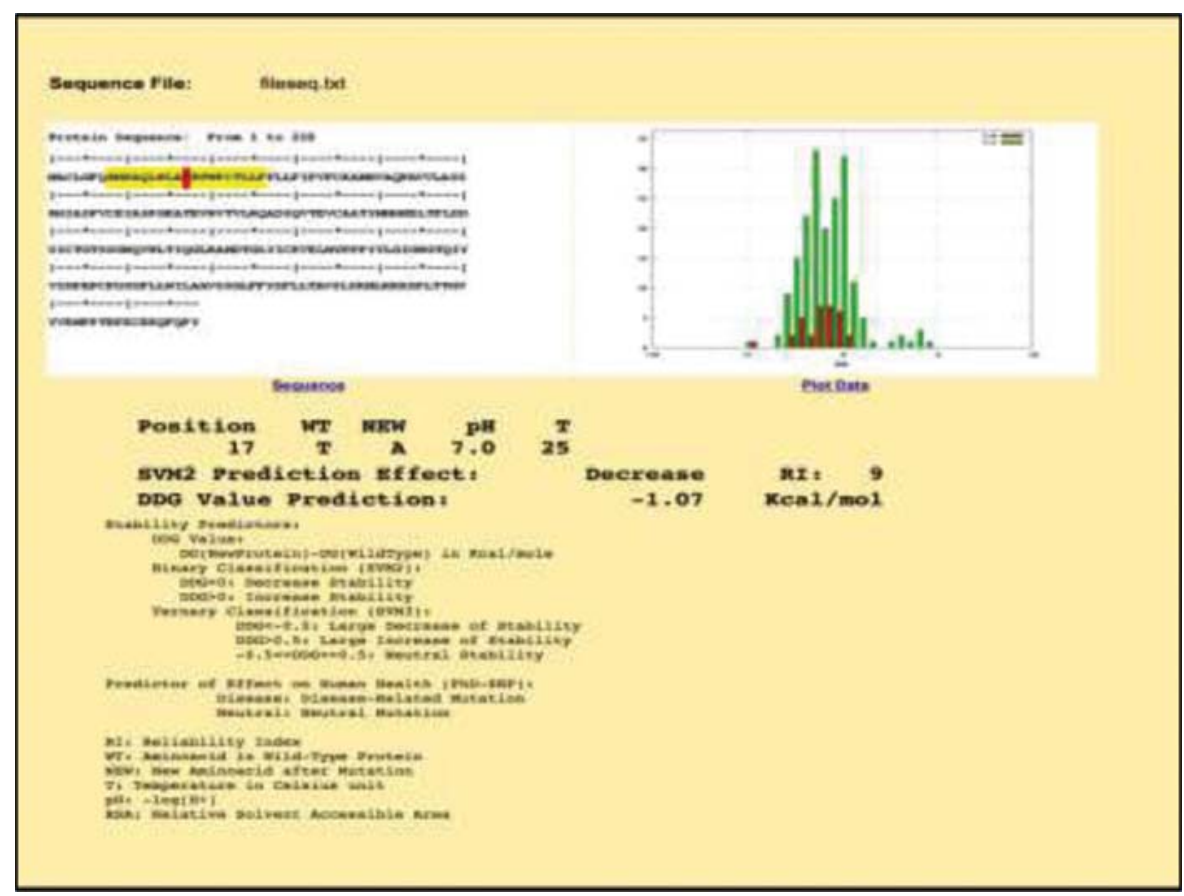

Fig. 2 Prediction of protein stability by 1-mutant program. 
tolerance to substitution. ${ }^{13}$ The algorithmic calculation methods of the hydrophobicity ${ }^{14}$ and $\alpha$-helix propensity ${ }^{15}$ that accompanied the CTLA-4 T17A change were also determined to help in predicting the alteration in the CTLA-4 signal peptide function.

\section{Data Analysis}

Statistical analysis was performed using SPSS software package, version 23 (SPSS, Inc.; Chicago, Illinois, United States). The mean difference between study group was assessed by using the Student's t-test. Qualitative data were presented as number of (\%), the comparisons of genotypes and alleles frequencies between patients and controls were assessed using the chi-squared $\left(\mathrm{x}^{2}\right)$ test and the Fisher's exact tests, and levels of risk for genotypes and alleles were expressed as odds ratio (OR) with a 95\% confidence interval $(95 \% \mathrm{CI})$. Deviation from Hardy-Weinberg equilibrium was performed by applying the equation $\left(\mathrm{p}^{2}+2 \mathrm{pq}+\mathrm{q}^{2}\right)$ to compare the observed frequencies with the expected frequencies of the different genotype distribution in patients and controls by using Pearson's $\mathrm{x}^{2}$ test of independence in SPSS. Statistical significance was considered at $p<0.05$.

\section{Results}

The study included 100 children with T1D (48 males and 52 females) and 100 unrelated healthy controls (44 males and 56 females).

- Table 1 showed the sociodemographic and clinical characteristics of study groups. There were no significant differences in the age and gender between patients and controls $(p>0.05)$. Compared with the controls, the patients showed significant high mean levels of $\mathrm{HbA}_{1 \mathrm{c}}(p=0.0003)$ and low mean level of body mass index $(p=0.01)$.
As shown in - Table 2, the frequency distribution of CTLA$4+49$ A/G genotypes and alleles showed significant differences between the patients and the controls $(p=0.00013$ and 0.0002 , respectively). The genotypic distribution was not deviated from the Hardy-Weinberg equilibrium in patients $\left(x^{2}=5.19, \mathrm{df}=2, p=0.08\right)$ and controls $\left(x^{2}=4.82, \mathrm{df}=2\right.$, $p=0.09$ ).

The GG homozygous and AG heterozygous genotypes were more frequent in patients than in controls (12 vs. $2 \%$ and 32 vs. 10\%, respectively). This difference was statistically significant $(p=0.01, \mathrm{OR}=6.68,95 \% \mathrm{CI}=1.46-30.69$ vs. $p=0.00, \mathrm{OR}=4.24,95 \% \mathrm{CI}=1.95-9.21$, respectively). At the same time, the CTLAAla ${ }^{16}(\mathrm{G})$ allele was significantly high in frequency in patients than in controls ( 28 vs. $7 \%, O R=5.16$, $95 \% \mathrm{CI}=2.77-9.56, p=0.00)$.

SIFT analysis score for the CTLA-4 SNP (rs231775) position at codon 17 (T17A) indicates evolutionary conservation of the gene and intolerance to substitution ( - Table 3 ) that my decrease the CTLA-4 protein stability as predicted by the I mutant analysis (-Fig. 2), most likely by affecting the polarity (from polar threonine to nonpolar alanine) of the CTLA-4 signal peptide chain (-Fig. 3). The threonine to alanine substitution at position 17 also leads to increase in the hydrophobicity and $\alpha$-helix propensity, two properties known to be important in the CTLA-4 signal peptide function (-Fig. 4).

\section{Discussion}

T1DM is one of the most frequent chronic diseases in children, and has become health problem in developing countries. ${ }^{17}$ Recently, associated studies have been conducted to address the association of polymorphisms in the CTLA-4 gene as a candidate gene with several autoimmune

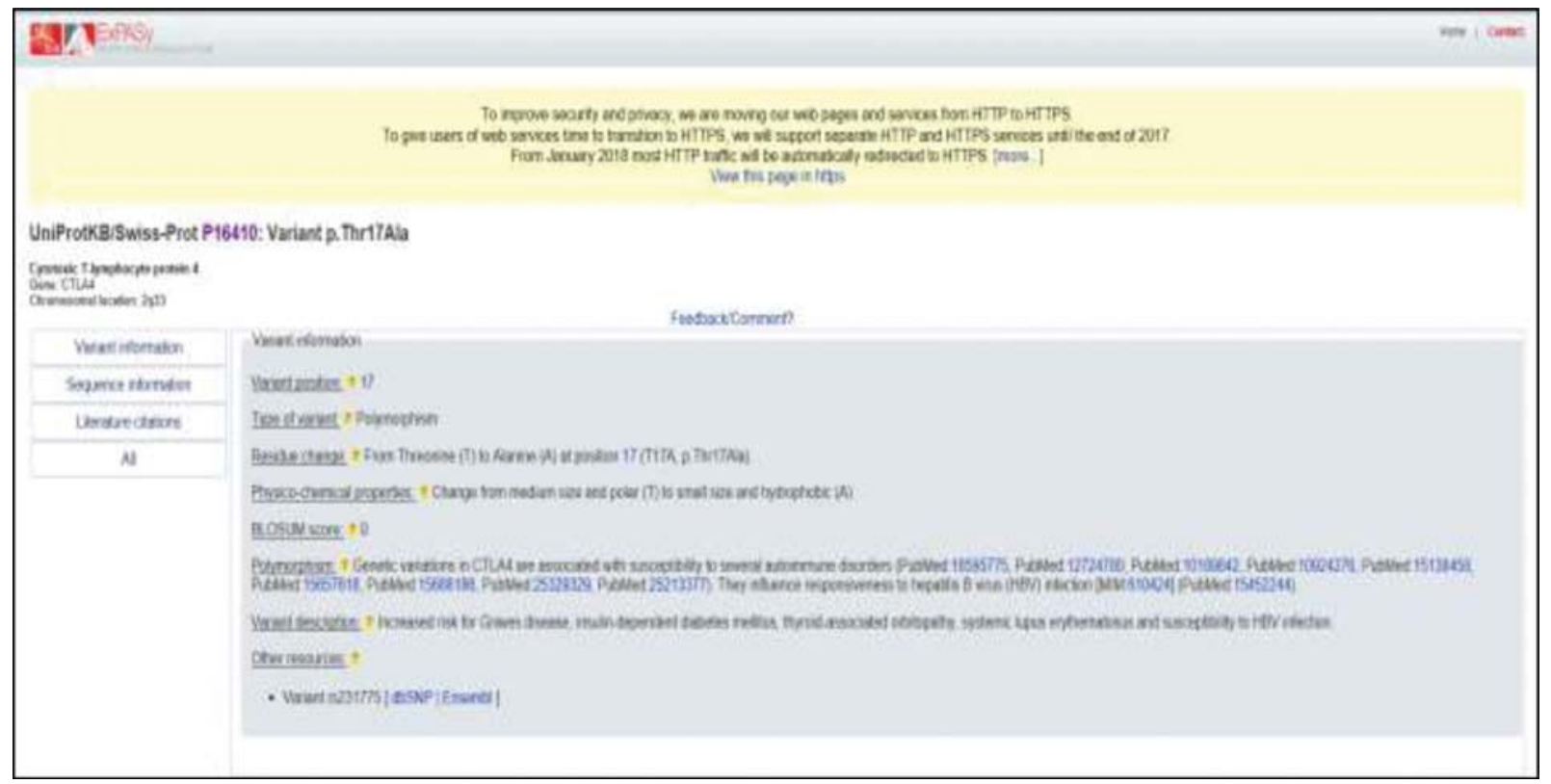

Fig. 3 The variation formation of the CTLA-4 SNP. This figure shows the variant formation for the CTLA-4 (rs231775) SNP position at codon 17 $(T / A)$, this SNP affects the polarity (from polar threonine to nonpolar alanine) of the CTLA-4 signal peptide chain. CTLA-4, cytotoxic T-lymphocyte antigen-4; SNP, single nucleotide polymorphism. 

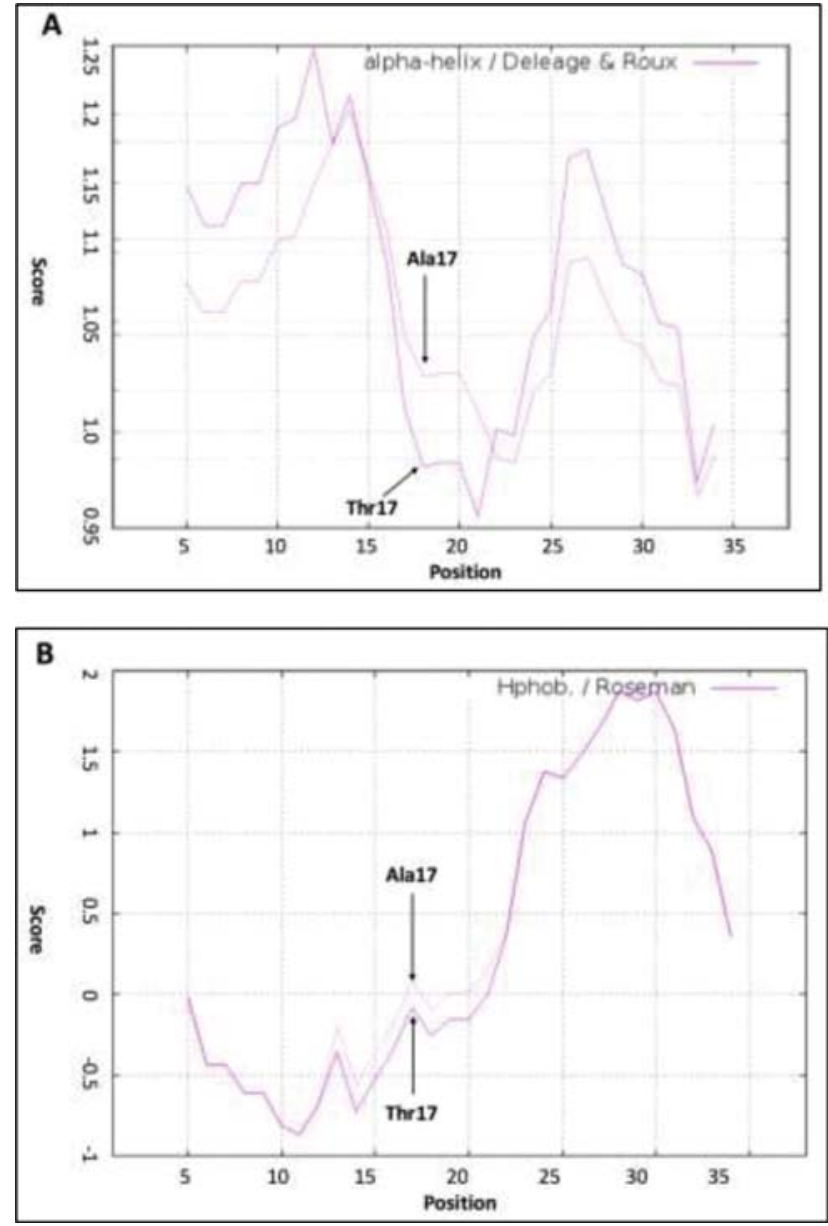

Fig. 4 The prediction of signal peptide function. Signal peptide function could be influences by factors that can be predicted by using algorithms available at ProtScale (us.expasy.org/cgi-bin/protscale.pl). (A) $\alpha$-helix propensity was calculated by Roseman method (1988), and (B) hydrophobicity by the Deléage and Roux Method (1987). The CTLA-4 T17A change resulted in a higher propensity to form $\alpha$-helices in the area directly adjacent to the change and an increased in hydrophobicity. CTLA-4, cytotoxic T-lymphocyte antigen-4.

diseases, ${ }^{6}$ particularly T1DM. ${ }^{7}$ The CTLA- $4+49$ A/G gene polymorphism was found to be the only known SNP that causes an amino acid exchange (threonine to alanine or +49 $\mathrm{A} / \mathrm{G}$ ) in exon 1 in the leader peptide sequence of the CTLA-4 protein, which can be associated with altered protein expression $^{4}$ and $\mathrm{T}$ cell activation. ${ }^{5}$

We studied the CTLA-4 ( $+49 \mathrm{~A} / \mathrm{G})$ polymorphism because it has been the most widely analyzed variant in different ethnic groups, and still with inconsistent findings. ${ }^{16,18-41}$ Furthermore, this is the first study investigated the effect of $+49 \mathrm{~A} / \mathrm{G}$ polymorphism among Sudanese children with T1DM, bearing in mind a recent data investigated this polymorphism among Sudanese adults with T1DM. ${ }^{9}$

Our study found that the frequency of G allele and GG homozygous genotype was significantly high in patients than in controls $(p=0.01)$. This finding consistent with previous studies in populations from our continent includes Egyptians $^{16,18}$ and Tunisians, ${ }^{19}$ together with other populations such as Indian, ${ }^{20}$ Caucasian and Asian,, ${ }^{21,22}$ Iranians, ${ }^{23-25}$ Estonian and Finnish, ${ }^{26}$ Chilean, ${ }^{27}$ and Russian. ${ }^{28}$ Other studies among Sudanese, ${ }^{9}$ Ghanaian, ${ }^{29}$ and other populations, ${ }^{30,31}$ did not prove this association. The OR provided by the GG homozygous genotype and G allele were high, suggesting their additive effect on the AG heterozygous genotype $(p=0.00)$ as seen in our study.

The presence of the $+49 \mathrm{~A} / \mathrm{G}$ at-risk $(\mathrm{G}$ ) allele in the CTLA- 4 molecule has been shown to be effective in inhibiting the activated $\mathrm{T}$ cell proliferation in vitro. ${ }^{32}$ This perception coincides with the high frequency of $G$ allele among our patients, and found to be consistent with results from other populations including Egyptians, ${ }^{16,33}$ Iranian, ${ }^{25}$ Turkish, ${ }^{34}$ Croatians, ${ }^{35}$ Belgian, ${ }^{36}$ Mexican-American, and Korean, ${ }^{37}$ and meta-analysis study in Asian population. ${ }^{38}$

However, lack of association between the aforementioned polymorphism and T1DM has been also reported in populations from Sudan, ${ }^{9}$ Czech, ${ }^{31}$ Turkey, ${ }^{34}$ Korea, ${ }^{38}$ Chile, ${ }^{39}$ Portugal, ${ }^{40}$ and Azerbaijan. ${ }^{41}$ The discrepancy in results between ethnic groups may be attributed to genetic heterogeneity relevant to ethnic diversity, to polymorphism coplayers (environmental factors, etc.), or to differences in methodologies and sample size used.

The CTLAAla ${ }^{16}(\mathrm{G})$ allele (homozygotes) located at the Nterminal of conserved position in the loop region of the signal peptide sequence introduces the hydrophobic amino acid alanine instead of threonine in the signal peptide sequence. This introduction, and based on our bioinformatics analysis, was somewhat associated with evolutionary conservation of the gene and intolerance that may decrease the CTLA-4 protein stability, affecting the polarity, and increase hydrophobicity and $\alpha$-helix propensity. These properties are collectively known to be important in signal peptide function. The consequences of these alterations may result in an aberrantly glycosylated product, alteration in proteins folding, and/or interaction with ER chaperones, which may finally lead to less functional expression of CTLA- 4 at the cell surface of their T cells than the normal Thr ${ }^{16}$ allele. $^{6}$ It is most likely that the one-third less expression of the mutant homozygous (GG) on the cell surface of T cells than the normal homozygous (AA) can lower the affinity of CTLA-4 for B7 molecule, skewing the negative balance exerted for damping $T$ cell activation. ${ }^{7,42}$

The small sample size in this study, concomitant with the large discrepancy in Sudanese ethnic groups, makes the power of association between the CTLA- $4+49 \mathrm{~A} / \mathrm{G}$ (rs231775) polymorphism and T1DM relatively weak and the overall data are not fully conclusive.

\section{Conclusion}

The study supported the proposition that CTLA- $4+49$ A/G polymorphism is associated with the risk of T1DM in Sudanese children, and the presence of the CTLA- $4 \operatorname{Thr}^{16}(\mathrm{G})$ allele (homozygous) represents an evolutionary change predisposed the risk for T1DM. This data warrant further studies with larger study population to verify our findings.

\section{Ethical Approval}

The informed consent was obtained from all the subjects and the study was approved by the University of Gezira 
Ethics Committee (UGEC) and was performed in accordance with Helsinki Declaration of 1975.

\section{Conflict of Interest \\ None declared.}

\section{Acknowledgments}

I would like to thank Dr. Mohammed Osman A/Wahid at the National Cancer Institute (NCI), University of Gezira (U of G), Sudan, for his technical support in the RFLP. I would also like to show earnest gratitude to the medical staff at Wad Medani Pediatric Hospital for their continual assistance during sampling.

\section{References}

1 Zheng P, Wu Y, Guo Y, Lee C, Liu Y. B7-CTLA4 interaction enhances both production of antitumor cytotoxic $\mathrm{T}$ lymphocytes and resistance to tumor challenge. Proc Natl Acad Sci U S A 1998;95 (11):6284-6289

2 Linsley PS, Brady W, Urnes M, Grosmaire LS, Damle NK, Ledbetter JA. CTLA-4 is a second receptor for the B cell activation antigen B7. J Exp Med 1991;174(03):561-569

3 Wang XB, Giscombe R, Yan Z, Heiden T, Xu D, Lefvert AK. Expression of CTLA-4 by human monocytes. Scand J Immunol 2002;55(01):53-60

4 Carreno BM, Bennett F, Chau TA, et al. CTLA-4 (CD152) can inhibit $T$ cell activation by two different mechanisms depending on its level of cell surface expression. J Immunol 2000;165(03): 1352-1356

5 Ostrov DA, Shi W, Schwartz JC, Almo SC, Nathenson SG. Structure of murine CTLA- 4 and its role in modulating $\mathrm{T}$ cell responsiveness. Science 2000;290(5492):816-819

6 Anjos S, Nguyen A, Ounissi-Benkalha H, Tessier MC, Polychronakos C. A common autoimmunity predisposing signal peptide variant of the cytotoxic T-lymphocyte antigen 4 results in inefficient glycosylation of the susceptibility allele. J Biol Chem 2002; 277(48):46478-46486

7 Mäurer M, Loserth S, Kolb-Mäurer A, et al. A polymorphism in the human cytotoxic T-lymphocyte antigen 4 ( CTLA4) gene (exon $1+49$ ) alters T-cell activation. Immunogenetics 2002;54 (01):1-8

8 Kavvoura FK, Ioannidis JP. CTLA-4 gene polymorphisms and susceptibility to type 1 diabetes mellitus: a HuGE Review and meta-analysis. Am J Epidemiol 2005;162(01):3-16

9 Alshareef SA, Omar SM, Hamdan HZ, Adam I. Cytotoxic T-lymphocyte antigen- $4+49 \mathrm{~A} / \mathrm{G}$ polymorphisms in Sudanese adults with type 1 diabetes and latent autoimmune diabetes. BMC Res Notes 2019;12(01):769

10 American Diabetes Association. Classification and diagnosis of Diabetes. Diabetes Care 2017;40(Suppl 1):S11-S24

11 Haneda $M$, Noda $M$, Origasa $H$, et al. Japanese clinical practice guideline for diabetes 2016. Diabetol Int 2018;9(01):1-45

12 Capriotti E, Calabrese R, Fariselli P, Martelli PL, Altman RB, Casadio R. WS-SNPs\&GO: a web server for predicting the deleterious effect of human protein variants using functional annotation. BMC Genomics 2013;14(Suppl 3):S6

13 Ng PC, Henikoff S. Predicting deleterious amino acid substitutions. Genome Res 2001;11(05):863-874

14 Deléage G, Roux B. An algorithm for protein secondary structure prediction based on class prediction. Anal Biochem 1987; 163:292-297

15 Roseman MA. Hydrophilicity of polar amino acid side-chains is markedly reduced by flanking peptide bonds. J Mol Biol 1988;200 (03):513-522
16 Mosaad YM, Elsharkawy AA, El-Deek BS. Association of CTLA-4 $(+49 \mathrm{~A} / \mathrm{G})$ gene polymorphism with type 1 diabetes mellitus in Egyptian children. Immunol Invest 2012;41(01):28-37

17 Osei K, Schuster DP, Amoah AG, Owusu SK. Diabetes in Africa. Pathogenesis of type 1 and type 2 diabetes mellitus in subSaharan Africa: implications for transitional populations. J Cardiovasc Risk 2003;10(02):85-96

18 Saleh HM, Rohowsky N, Leski M. The CTLA4-819 C/T and +49 A/G dimorphisms are associated with type 1 diabetes in Egyptian children. Indian J Hum Genet 2008;14(03):92-98

19 Benmansour J, Stayoussef M, Al-Jenaidi FA, et al. Association of single nucleotide polymorphisms in cytotoxic T-lymphocyte antigen 4 and susceptibility to autoimmune type 1 diabetes in Tunisians. Clin Vaccine Immunol 2010;17(09):1473-1477

20 Gunavathy N, Asirvatham A, Chitra A, Jayalakshmi M. Association of CTLA-4 and CD28 gene polymorphisms with type 1 diabetes in South Indian population. Immunol Invest 2019;48(06):659-671

21 Wang B, Du W, Jia Y, Zhang X, Ma G. Cytotoxic T-lymphocyteassociated protein $4+49 \mathrm{~A} / \mathrm{G}$ polymorphisms contribute to the risk of type 1 diabetes in children: An updated systematic review and meta-analysis with trial sequential analysis. Oncotarget 2017;8(06):10553-10564

22 Tang ST, Tang HQ Zhang Q Wang CJ, Wang YM, Peng WJ. Association of cytotoxic T-lymphocyte associated antigen 4 gene polymorphism with type 1 diabetes mellitus: a metaanalysis. Gene 2012;508(02):165-187

23 Ahmadi S, Rostamzadeh J, Khosravi D, Shariati P, Shakiba N. Association of CTLA-4 gene 49A/G polymorphism with the incidence of type 1 diabetes mellitus in the Iranian Kurdish population. Pak J Biol Sci 2013;16(24):1929-1935

24 Ranjouri MR, Aob P, Mansoori Derakhshan S, Shekari Khaniani M, Chiti H, Ramazani A. Association study of IL2RA and CTLA4 gene variants with type I diabetes mellitus in children in the northwest of Iran. Bioimpacts 2016;6(04):187-193

25 Mojtahedi Z, Omrani GR, Doroudchi M, Ghaderi A. CTLA-4 +49 A/G polymorphism is associated with predisposition to type 1 diabetes in Iranians. Diabetes Res Clin Pract 2005;68(02):111-116

26 Douroudis K, Laine AP, Heinonen M, et al. Association of CTLA4 but not ICOS polymorphisms with type 1 diabetes in two populations with different disease rates. Hum Immunol 2009;70(07):536-539

27 Angel B, Balic I, Santos JL, Codner E, Carrasco E, Pérez-Bravo F. Associations of the CTLA-4 polymorphisms with type 1 diabetes in a Chilean population: case-parent design. Diabetes Res Clin Pract 2009;85(03):e34-e36

28 Chistiakov DA, Savost'anov KV, Nosikov VV. CTLA4 gene polymorphisms are associated with, and linked to, insulin-dependent diabetes mellitus in a Russian population. BMC Genet 2001;2:6

29 Osei-Hyiaman D, Hou L, Zhiyin R, et al. Association of a novel point mutation (C159G) of the CTLA4 gene with type 1 diabetes in West Africans but not in Chinese. Diabetes 2001;50(09):2169-2171

30 Kumar N, Kaur G, Kanga U, et al. CTLA4+49G allele associates with early onset of type 1 diabetes in North Indians. Int J Immunogenet 2015;42(06):445-452

31 Cinek O, Drevínek P, Sumník Z, et al. The CTLA4 +49 A/G dimorphism is not associated with type 1 diabetes in Czech children. Eur J Immunogenet 2002;29(03):219-222

32 Kouki T, Sawai Y, Gardine CA, Fisfalen ME, Alegre ML, DeGroot LJ. CTLA- 4 gene polymorphism at position 49 in exon 1 reduces the inhibitory function of CTLA-4 and contributes to the pathogenesis of Graves' disease. J Immunol 2000;165(11):6606-6611

33 Arafa RM, Desouky SM, Emam SM, Abed NT, Mohamed SY. Detection of cytotoxic T-lymphocyte associated antigen-4 gene polymorphism in type 1 diabetes mellitus. Egypt J Immunol 2015; 22(01):49-57

34 Çelmeli F, Türkkahraman D, Özel D, Akçurin S, Yegin O. CTLA-4 $(+49 \mathrm{~A} / \mathrm{G})$ polymorphism and type-1 diabetes in Turkish children. J Clin Res Pediatr Endocrinol 2013;5(01):40-43 
35 Korolija M, Renar IP, Hadzija M, et al. Association of PTPN22 C1858T and CTLA-4 A49G polymorphisms with type 1 diabetes in Croatians. Diabetes Res Clin Pract 2009;86(03):e54-e57

36 Van der Auwera BJ, Vandewalle CL, Schuit FC, et al. CTLA-4 gene polymorphism confers susceptibility to insulin-dependent diabetes mellitus (IDDM) independently from age and from other genetic or immune disease markers. The Belgian Diabetes Registry. Clin Exp Immunol 1997;110(01):98-103

37 Marron MP, Raffel LJ, Garchon HJ, et al. Insulin-dependent diabetes mellitus (IDDM) is associated with CTLA4 polymorphisms in multiple ethnic groups. Hum Mol Genet 1997;6(08): 1275-1282

38 Chen Z, Fei M, Fu D, et al. Association between cytotoxic T lymphocyte antigen- 4 polymorphism and type 1 diabetes: a meta-analysis. Gene 2013;516(02):263-270
39 Balic I, Angel B, Codner E, Carrasco E, Pérez-Bravo F. Association of CTLA-4 polymorphisms and clinical-immunologic characteristics at onset of type 1 diabetes mellitus in children. Hum Immunol 2009;70(02):116-120

40 Lemos MC, Coutinho E, Gomes L, et al. The CTLA4 +49 A/G polymorphism is not associated with susceptibility to type 1 diabetes mellitus in the Portuguese population. Int J Immunogenet 2009;36(03):193-195

41 Ahmedov G, Ahmedova L, Sedlakova P, Cinek O. Genetic association of type 1 diabetes in an Azerbaijanian population: the HLADQ -DRB1*04, the insulin gene, and CTLA4. Pediatr Diabetes 2006;7(02):88-93

42 Kristiansen OP, Larsen ZM, Pociot F. CTLA-4 in autoimmune diseases-a general susceptibility gene to autoimmunity? Genes Immun 2000;1(03):170-184 